Meta

Journal des traducteurs

Translators' Journal

\title{
Translating Epistemic Adverbs from English into Spanish: Evidence from a Parallel Corpus
}

\section{Noelia Ramón}

Volume 54, numéro 1, janvier 2009

URI : https://id.erudit.org/iderudit/029794ar

DOI : https://doi.org/10.7202/029794ar

Aller au sommaire du numéro

Éditeur(s)

Les Presses de l'Université de Montréal

ISSN

0026-0452 (imprimé)

1492-1421 (numérique)

Découvrir la revue

Citer cet article

Ramón, N. (2009). Translating Epistemic Adverbs from English into Spanish: Evidence from a Parallel Corpus. Meta, 54(1), 73-96.

https://doi.org/10.7202/029794ar
Résumé de l'article

L'expression de la modalité est un exemple très complexe des relations entre forme et fonction dans une même langue et, plus encore, entre plusieurs langues. En particulier, les adverbes modaux sont tenus pour être problématiques dans une perspective contrastive à cause de leur multifonctionnalité en anglais (Aijmer 2005). À partir d'une analyse de corpus, l'article étudie l'expression de la possibilité épistémique à travers trois adverbes de modalité très courants en anglais (certainly, probably, possibly) et leur traduction en espagnol. Le but est d'identifier des tendances dans les traductions de ces adverbes épistémiques, ce qui pourrait contribuer à une meilleure compréhension des différentes fonctions sémantiques que les locuteurs anglophones attribuent à ces unités lexicales. L'analyse montre que l'omission des adverbes de modalité dans les traductions espagnoles peut être considérée comme un signe du degré de grammaticalisation atteint par ces adverbes en anglais. Les résultats de cette étude sont utiles non seulement pour la pratique et l'apprentissage de la traduction, mais aussi pour la linguistique descriptive.
Ce document est protégé par la loi sur le droit d'auteur. L'utilisation des services d’Érudit (y compris la reproduction) est assujettie à sa politique d'utilisation que vous pouvez consulter en ligne.

https://apropos.erudit.org/fr/usagers/politique-dutilisation/ 


\title{
Translating Epistemic Adverbs from English into Spanish: Evidence from a Parallel Corpus ${ }^{1}$
}

\author{
NOELIA RAMÓN \\ University of León, León, Spain \\ noelia.ramon@unileon.es
}

\begin{abstract}
RÉSUMÉ
L'expression de la modalité est un exemple très complexe des relations entre forme et fonction dans une même langue et, plus encore, entre plusieurs langues. En particulier, les adverbes modaux sont tenus pour être problématiques dans une perspective contrastive à cause de leur multifonctionnalité en anglais (Aijmer 2005). À partir d'une analyse de corpus, l'article étudie l'expression de la possibilité épistémique à travers trois adverbes de modalité très courants en anglais (certainly, probably, possibly) et leur traduction en espagnol. Le but est d'identifier des tendances dans les traductions de ces adverbes épistémiques, ce qui pourrait contribuer à une meilleure compréhension des différentes fonctions sémantiques que les locuteurs anglophones attribuent à ces unités lexicales. L'analyse montre que l'omission des adverbes de modalité dans les traductions espagnoles peut être considérée comme un signe du degré de grammaticalisation atteint par ces adverbes en anglais. Les résultats de cette étude sont utiles non seulement pour la pratique et l'apprentissage de la traduction, mais aussi pour la linguistique descriptive.
\end{abstract}

\begin{abstract}
The expression of modal meanings is an area of great complexity in the relationship between form and function in a single language and cross-linguistically. Modal adverbs in particular are considered to be problematic from a contrastive perspective due to their multifunctionality in English (Aijmer 2005). This paper is a corpus-based study of the expression of epistemic possibility by means of three common modal adverbs in English (certainly, probably, possibly) and the translational options chosen in Spanish for expressing those meanings. The aim is to identify trends in the translations of these epistemic adverbs that contribute to a better understanding of the various semantic functions that native speakers attribute to these units. The analysis shows that the omission of modal adverbs in the translations may be considered as an indicator of the degree of grammaticalization attained by these adverbs in English. The results provide useful information not only in the field of translator training and practice, but also in descriptive linguistics.
\end{abstract}

MOTS-CLÉS/KEYWORDS

epistemic adverbs, grammaticalization, modal meanings, parallel corpus, Spanish

\section{Introduction}

This paper is a corpus-based contrastive study of three different English epistemic modal adverbs indicating varying degrees of likelihood - certainly, probably and possibly - and their corresponding translations into Spanish as they were found in a large English-Spanish parallel corpus of contemporary texts. Modal adverbs are the focus of interest of a number of recent studies due to their multifunctionality and to 
the gradual development of some of these adverbs into pragmatic markers. A detailed analysis of the use of these three adverbs in context, their syntagmatic and paradigmatic features and their co-occurrences with other modal markers is complemented by the analysis of the corresponding Spanish translations. The main aim of this paper is to reveal the various translation possibilities that translators actually use to convey the meanings of these English adverbs, and to what extent these translations disclose information of the various functions of those adverbs in the source language.

Modality as a broad semantic field has traditionally attracted the interest of linguists for a number of reasons (Perkins 1983, Coates 1983, Palmer 1990, Nuyts 2001, Facchinetti et al. 2003). On the one hand, the term "modality" is a complex concept that includes a great number of possible meanings related to non-factuality, ranging from those expressing degrees of likelihood to those expressing wishes, doubts, orders, etc. On the other hand, because modality is such a fuzzy meaning conglomerate, it comes as no surprise that there is a wide range of different linguistic resources for actualising modal meanings of various types, from specialized categories such as the English modal verbs, to certain lexical verbs, adverbs, adjectives, or the elusive grammatical category of mood, which is particularly common in Spanish. From a cross-linguistic perspective, modality is one of the most widely studied areas too (Aijmer 1999, Facchinetti \& Palmer 2004, Márquez Reiter 2005, Ramón (2006)).

A traditional attempt to organize the multifaceted field of modality is the distinction between root or deontic modality and epistemic modality. Even though this seems a highly simplified picture, there is general consensus regarding the definition of these two types of modality and this distinction has proved to be very useful in describing the modal systems of many different languages in the world. Root modality is agent-oriented and deals with meanings related to permission and obligation, whereas epistemic modality “is concerned with the speaker's assumptions or assessment of possibilities, and in most cases it indicates the speaker's confidence or lack of confidence in the truth of the proposition expressed." (Coates 1995: 55).

Recent research (Aijmer 2002, 2005) has dwelled on the multifaceted nature of certain epistemic adverbs that seem to have developed new pragmatic meanings with the passing of time. This shift in meaning is an example of grammaticalization and represents a new problem in the translation of epistemic adverbs. Aijmer states that "since modality does not add anything to the propositional content of an utterance, it often disappears in the translation." (Aijmer 2002: 97). I will claim in this paper that omissions of epistemic items in translations can be interpreted in a meaningful way, in particular with respect to the uses of modal adverbs as pragmatic markers. Discourse markers in general tend to be difficult to translate into a different language, since they rest heavily on highly idiomatic uses of the language and thus require a very good command of the target language to be able to convey a similar type of meaning. Elusive meanings that are difficult to pinpoint such as the ones expressed by pragmatic markers are the types of meanings that are most likely to be omitted in translations, since they do not add new propositional content to the text, but rather modulate it according to the author's needs and the organization of discourse. In this paper I try to show that Spanish translations can be a good way to discriminate the extent to which some modal adverbs have been grammaticalized and are now being used as pragmatic markers in English. 


\section{Theoretical Background}

\subsection{Epistemic modality}

Epistemic modality is the expression of the speaker's stance (Biber et al. 1999) and it is often linked to philosophical approaches and to logic, as it is concerned with the concept of truth of a particular situation or proposition as perceived and expressed by the speaker (Hale 2000). Epistemic modality is organized in the form of a cline with varying degrees of likelihood. This paper deals with the expression of epistemic modality in English and its translation into Spanish, as well as with the semantic shifts affecting certain epistemic markers and how these shifts are represented in translations.

In English, epistemic modal meanings are most often associated with the expression of modal verbs, and it is true that these linguistic units have specialised in the actualization of these particular functions. However, there are a few modal adverbs that can also be used to express epistemic force, alone or in conjunction with a modal verb, to reinforce the modal function, as in examples (1) and (2):

(1) The term has a few weeks to run and I wonder if I can possibly advance beyond the position I have reached now, if I could supplant a real athlete - I wonder if it is even worth trying... (FBW1E.s553)

(2) He will probably die in his late teens or early twenties. (EWJ1E.s178)

As a matter of fact,

[t]here are very few adverbs that may occur with epistemic modals (or even modals in general). They are confined to those that themselves express judgements, and so occur largely pleonastically - possibly, perhaps, etc., for possibility, and surely, certainly, etc., for necessity. (Palmer 1979: 57)

In this paper, I focus on the expression of epistemic modality by means of certain adverbs in English and their translations into Spanish.

The traditional concept of "epistemic modality" partly overlaps with more recent studies devoted to the category of "evaluation," "the broad cover term for the expression of the speaker or writer's attitude or stance towards, viewpoint on, or feelings about the entities or propositions that he or she is talking about" (Thompson \& Hunston 2000: 5). This is a particularly complex field of study, since the degree of commitment of the author may vary a lot, as we have already seen, and may be represented linguistically in many different ways. The broad category of "evaluation" and the linguistic items that embody it have been referred to by various authors using different terms, such as "disjuncts" (Quirk et al. 1985), "evidentiality" (Chafe 1986), "stance" (Biber and Finegan 1989), "attitude" (Halliday 1994), "discourse markers" (Fraser 1999), and "pragmatic markers" (Aijmer 2005). These elements are not part of the propositional content of discourse, but rather comment of the proposition itself, and may express a variety of functions in addition to opinion, mainly the construction and maintenance of interpersonal relationships and the organization of discourse. 


\subsection{Grammaticalization and pragmatic markers}

As Aijmer $(2002,2005)$ points out, a number of the traditional epistemic adverbs in English are undergoing a process of grammaticalization and developing into textual and pragmatic markers. In this process, some adverbs that have typically been associated with the expression of stance are increasing their semantic range, and can be used in addition to express emphasis on the part of the speaker or to relate the following proposition to the previous discourse or to the speaker's attitude as in example (3):

(3) Certainly it was a fair assumption that Prien had the benefit of inside information. (EHJ1E.s375)

In example (3), the adverb certainly indicates a strong commitment on the part of the speaker, but it also acts as a link between two parts of discourse, as we expect that there must have been some type of evidence mentioned previously in the text to justify the speaker's certainty.

Where form is concerned, pragmatic markers tend to occur in sentence-marginal positions or parenthetically, as can be seen in the initial position the adverb occupies in example (3). However, many other pragmatic markers have become fused with the rest of the sentence and are therefore to be considered on the boundary between proper adverbs and discourse markers. In English, this is the case of units such as really, actually, of course, etc. This flexibility with respect to position is only apparent in some cases. I will claim in this paper that pragmatic markers tend to form collocations and patterns in text, precisely because of their textual function (see section 4.3. below).

From a functional perspective, modal adverbs with epistemic meanings contribute to the expression of interpersonal meanings, i.e., they represent the speaker's stance with respect to the proposition. However, languages change over time and many modal adverbs are noted to have developed textual functions linking together the different parts of a text at a suprasentential level. In these cases, adverbs such as well, really, of course and others lose part of their epistemic force and should rather be treated as pragmatic markers. This shift in meaning of some epistemic adverbs has been explained as a process of grammaticalization of these linguistic units as discourse markers or pragmatic markers. This is a very subtle evolution in some cases, but clearly noticeable in others, although it affects different types of particles, in particular adverbs, in different degrees. The analysis of the translations of a number of epistemic adverbs in this paper will enable us to discriminate the various types of semantic functions that may be performed by these linguistic units by identifying translation trends.

\section{Method and Data Selection}

The working procedure followed in this paper is the one developed by the ACTRES ${ }^{2}$ research group at the University of León (Spain). The ACTRES Project is a long-term, translation-oriented, research endeavour that has been running for several years now. This project is aimed at exploiting cross-linguistic analyses between English and Spanish in order to investigate translated language and find applications mainly in the field of translation practice, translator training and translation quality assess- 
ment. Various types of computerised corpora have been used to date to carry out different types of contrastive studies involving English and Spanish. Descriptive studies have been carried out in a number of functional-semantic areas (the expression of quantification, characterization, degree, modality, etc. in English and Spanish (Ramón 2003, Rabadán et al. 2004)) using data extracted from two large monolingual reference corpora that have been trimmed to comparable sizes of around 30 million words each, i.e., Cobuild for English and CREA (Corpus de Referencia del Español Actual) for Spanish.

In more recent times, a parallel corpus has been compiled and aligned containing original English texts and their corresponding Spanish translations. This translation corpus includes written material from a variety of different registers (fiction, non-fiction, press \& miscellanea) published in English in the year 2000 or later, thus representing the contemporary stage of the English language. Together with the corresponding translations into peninsular Spanish, these texts form what is known as the P-ACTRES corpus (Parallel ACTRES). The P-ACTRES corpus is still under construction and contains today over two million words, approximately one million words per language. The texts included vary in length depending on the register. In the case of books, the corpus contains fragments approximately 15,000 words long. The exact length varies depending on the text, since chapter divisions were considered so that all fragments were complete textual pieces. In the case of newspaper and magazine articles the texts included are complete units of around 1,000 words each for the former and around 3,000 words each for the latter. The data for this study have been extracted from a smaller sample of parallel texts that have been aligned at sentence level and can be searched with the Corpus Work Bench browser $(\mathrm{CWB})^{3}$. This aligned version contains over one million three-hundred thousand words, distributed among fiction, non-fiction and press as follows:

TABLE 1

Contents of the English-Spanish Parallel Corpus

$\begin{array}{llll} & \text { ENGLISH } & \text { SPANISH } & \text { TOTAL } \\ \text { Books - fiction } & 295,207 & 302,818 & 598,025 \\ \text { Books - non-fiction } & 186,994 & 207,092 & 394,086 \\ \text { Newspapers } & 85,441 & 94,912 & 180,353 \\ \text { Magazines } & 61,721 & 69,218 & 130,939 \\ \text { TOTAL } & 629,363 & 674,040 & \mathbf{1 , 3 0 3 , 4 0 3}\end{array}$

For this study, three epistemic adverbs have been selected in English belonging to three different degrees of likelihood in the expression of epistemic modality: certainly, for a high degree of probability, probably, for a somewhat lower degree, and possibly, for the lowest degree of likelihood. These adverbs correspond to the most typical units in Hoye's "epistemic trichotomy of certainty, probability and possibility" (Hoye 1997: 240). All the instances of these three adverbs in our parallel corpus have been analysed and the corresponding translations have been classified into groups. The distribution of the various translation possibilities that correspond to each epistemic adverb provided us with a detailed picture of the expression of epistemic modality in Spanish, as well as with evidence of the process of grammaticalization that affects some English adverbs and turns them into pragmatic markers (Aijmer 2002). 
The three adverbs selected for this study end in $-l y$, and this will be relevant for the analysis of the corresponding Spanish translations. The Spanish suffix -mente to form adverbs is stylistically marked for being longish and cumbersome and tends to be avoided by native speakers who regularly replace them by "periphrastic constructions, usually adjectival or prepositional phrases, which function adverbially" (Hoye 1997: 253). Bearing in mind the high frequency of -ly adverbs in English, it is reasonable to expect an overuse of -mente adverbs in translations from English into Spanish due to the influence of the source language.

It has been amply demonstrated in the past that translation corpora can be a valuable tool for exploring semantic and pragmatic phenomena in a source language and that they provide answers to questions that cannot easily be answered on the basis of the analysis of a single language. (Aijmer 2005: 86).

I will demonstrate in this paper that the translational options found can be used as an indicator to identify specific features of the source units. In this case translations may help in determining varying degrees of grammaticalization in certain epistemic adverbs. In addition, I will claim in this paper that the translations of particular linguistic items can provide information about them that is difficult to observe otherwise in a monolingual analysis.

\section{Descriptive Analysis}

\subsection{The translations of certainly}

The adverb certainly indicates strong agreement (or disagreement, if in a negative environment) and is therefore considered to express a high degree of likelihood. If this adverb is used, it is because the addressee may have some doubts that need to be clarified by the use of certainly, which is employed with a clearly emphatic sense. In our parallel corpus there were 91 cases of the English adverb certainly. Two of these instances were modifiers, not adverbials, and were not included in this study. Only in 14 cases did the adverb co-occur with a modal verb: in 7 cases with will, in 5 cases with would, in 1 case with could and in 1 case with can. In all of these cases, the combination was "modally harmonic" (Lyons 1977), i.e., the adverb was used to reinforce the meaning conveyed by the modal verb.

Table 2 below shows the translations found for the English adverb certainly in the P-ACTRES corpus:

TABLE 2

Translations of certainly in Spanish

RESOURCE

Desde luego

Omission

Sin $d u d a$

Ciertamente

Superlative: más / menos

Con (toda) certeza

Seguro

No hay/cabe duda

Con (tanta/toda) seguridad
NUMBER OF CASES

24

17

9

8

5

5

4

4

2
PERCENTAGE

$26.96 \%$

$19.1 \%$

$10.11 \%$

$8.98 \%$

$5.61 \%$

$5.61 \%$

$4.49 \%$

$4.49 \%$

$2.24 \%$ 


$\begin{array}{lcc}\text { Evidentemente } & 1 & 1.12 \% \\ \text { Seguramente } & 1 & 1.12 \% \\ \text { Verdaderamente } & 1 & 1.12 \% \\ \text { Claro } & 1 & 1.12 \% \\ \text { evidente } & 1 & 1.12 \% \\ \text { Sin lugar a dudas } & 1 & 1.12 \% \\ \text { De ningún modo } & 1 & 1.12 \% \\ \text { Por supuesto } & 1 & 1.12 \% \\ \text { Por cierto } & 1 & 1.12 \% \\ \text { Por lo menos } & 1 & 1.12 \% \\ \text { Lexical verb esperar + subjunctive mood } & 1 & 1.12 \% \\ \text { TOTAL } & \mathbf{8 9} & \end{array}$

The data show that over 25\% of cases of the English modal adverb certainly were translated into Spanish by the prepositional phrase (PP) desde luego, as in examples (4) and (5):

(4) If not exactly his own, it's certainly one he has lifted, and used to stunning effect. (FCJ1E.s752)

Si no es exactamente suya, desde luego la ha expuesto y utilizado con asombroso efecto. (FCJ1S.s738)

(5) Certainly Gloria had done so. (FCJ2E.s289)

Gloria, desde luego, así lo había hecho. (FCJ2S.s288)

This PP is highly idiomatic in Spanish for expressing a strong commitment on the part of the speaker with respect to his/her belief of the truth of the proposition. In addition, a number of other PPs with similar meanings were used with the same function, notably sin duda (10\%), con certeza (5\%), con seguridad (2\%), sin lugar a dudas (1\%), de ningún modo (1\%), por supuesto (1\%), por cierto (1\%). In these cases, the noun in the PP is the one that carries the epistemic force, be it in the negative as in sin duda ("with no doubt"), or in the positive as in con certeza ("with certainty") or con seguridad ("with sureness"). Altogether, in our corpus PPs account for $50 \%$ of the translational options of the English adverb certainly. Examples (6) and (7) illustrate the uses of two different PPs in Spanish:

(6) The term will certainly be an interesting one and not without humour. (FBW1E. s208)

El trimestre va a resultar sin duda interesante e incluso puede que divertido. (FBW1S. s209)

(7) It had most certainly once been the property of King August. (FMEI1E.s88)

Casi con certeza había sido en un tiempo propiedad del rey Augusto. (FMEI1S.s88)

This wide range of options in the form of a PP ties in with the well-know typological nature of the Spanish language, which tends towards an analytic structure and therefore makes heavy use of PPs for many types of adverbial meanings to the detriment of the corresponding single-word adverbs typically ending in the suffix -mente (Hoye 1997: 253). The cognate of the English form certainly, the Spanish adverb ciertamente, does appear in the list and accounts for less than $10 \%$ of the translations, as in example (8). 
(8) Certainly this story moved and, in equal measure, mobilised everyone against us. (EPJ1E.s352)

Ciertamente este relato conmovió a la gente y, en igual medida, indispuso a todos contra nosotros. (EPJ1S.s334)

Three additional variants of adverbs in -mente also occur, but with just one case each: evidentemente, seguramente and verdaderamente.

(9) But certainly, the post-invasion period "has proved to be very tough... tougher than we anticipated." (PATG27E.s27)

Pero, evidentemente, el periodo tras la invasión "ha resultado ser muy difícil... más difícil de lo que preveíamos." (PATG27S.s25)

Modal adverbs ending in - mente do not seem to be frequent options of translators when dealing with the English adverb certainly and we can therefore infer that they are not particularly popular among native speakers of Spanish for expressing the meanings related to evidentiality and commitment on the part of the speaker. All in all, only $12 \%$ of the translational options correspond to one of these modal adverbs in Spanish. While -ly adverbs are rather neutral style in English, Spanish adverbs ending in -mente carry strong stylistic and pragmatic connotations. As a group, they are considered rather formal and tend to be avoided by native speakers because of their length, which makes them cumbersome and less flexible than PPs, which are used much more readily to express adverbial meanings (Hoye 1997; Rabadán et al. 2006). An overuse of -mente adverbs in translated Spanish may actually be considered an indicator of translationese, i.e., instances in translated language where the influence of the source language can be detected (Mauranen 2000, 2004). Comparing data from original Spanish (CREA) and the Spanish translations in PACTRES, ciertamente occurs slightly more often in translated texts than in original Spanish texts: 18 cases per million words in original texts versus 26 per million words in translations. However, for this particular adverb the difference is not statistically significant $(\mathrm{p} \text {-value }=0.096)^{4}$.

The second option most commonly taken by Spanish translators to convey the meaning of certainly was sheer omission, with nearly $20 \%$ of cases. This is probably the most striking fact in the analysis of this particular adverb. The following are some examples:

(10) I'll take care of the money, and I'll certainly keep the country frightened. (FGJ3E. s527)

Yo me encargaré del dinero y de mantener al país en vilo. (FGJ3S.s519)

(11) "No," I agreed, "but I can certainly prove he never carved it." (FWM1E.s492)

- No -asentí-, pero puedo probar que no la talló él. (FWM1S.s478)

In these cases, it seems that the translators have assumed that the degree of certainty implied by this particular adverb is virtually similar to absolute certainty, and he/she therefore uses the indicative mood and no sign of epistemic modality whatsoever in the Spanish translation. This omission points towards the idea that certainty is not a type of modality at all, but rather one of the ends of the scale of factuality. Epistemic modality is a cline going from what is extremely likely to what is extremely unlikely from the point of view of the speaker, and certainty implies that there is no room for doubt. If the speakers in these cases are certain of the truth 
of the proposition, we could ask ourselves why the modal adverb certainly is being used at all. The indicative mood would be the unmarked choice for expressing factuality, reality, and absolute truth. The use of an additional epistemic adverb seems somewhat superfluous and even confusing. The answer to this question seems to be that speakers of English only use the adverb certainly when they are not really certain. I claim that in the cases where certainly is omitted in the translations it does not act as an epistemic adverb, but rather carries out a different function related to the textual organization of discourse. In these cases, certainly is functioning as a pragmatic marker expressing stance only marginally and mainly being used as a link between two different parts of the text. For example, in (10) above I consider that the adverb is used to emphasize the enumeration and is, therefore, being employed here with a clearly additive meaning, on top of reinforcing the speaker's stance and commitment with respect to the action of the verb. Similarly, in (11) the adverb certainly suggests that there is some type of contrast involved between a previous part of the discourse about which the speaker is not so certain.

Why are these cases systematically omitted in translations? The reasons may be varied: a) pragmatic discourse markers are often difficult to convey cross-linguistically because a slightly different effect may be achieved; b) on the other hand, the lack of pragmatic markers is an indicator of simplification, a feature typically identified as characterizing translated language in general (Baker 1998).

One case of omission deserves a separate comment:

(12) If I came up too fast from this depth, I would certainly get decompression sickness and possibly die. (FPT1E.s1230) But I couldn't stop myself from drifting upwards. (FPT1E.s1231) I just couldn't stop myself. (FPT1E.s1232)

Si ascendía demasiado rápido desde aquella profundidad podía morir por una brusca descompresión, pero no podía evitar dejarme arrastrar hacia arriba, no lo podía evitar. (FPT1S.s947)

Again, in (12) the adverb indicates not only a high degree of likelihood, but also functions as a pragmatic link reinforcing the relationship between the condition and the probable result if the condition is fulfilled. Here, the Spanish translator has opted for the use of the lexical verb poder in the past tense, which is used to express only a very low degree of likelihood. No additional epistemic or pragmatic particle appears in the Spanish translation and this results in a considerable downtoning of the epistemic force.

In about $7 \%$ of cases the English adverb certainly was modulated into a Spanish construction including an adjective that expresses a high degree of likelihood: seguro, claro, evidente. These constructions all follow a common structural pattern: copula + adjective + que, as in (13) and (14):

(13) A few years later, number 19 adored the racket made by those county people, and they certainly adored him. (FGJ2E.s73)

Unos años más tarde, el número 19 adoraba el jaleo que armaban los del condado y estaba claro que éstos le adoraban a él. (FGJ2S.s71)

(14) He was too far away to be recognized, and he certainly wanted to be alone. (FGJ2E. s356)

Estaba demasiado lejos para que lo reconocieran y era evidente que deseaba estar solo. (FGJ2S.s351) 
The P-ACTRES corpus included a few cases (about 7\% of the total) where the meaning of the English adverb certainly was modulated into constructions in Spanish including the superlatives más and menos, for the positive and negative sense, respectively, marking the target text with highly idiomatic and somewhat colloquial expressions as in (15) and (16):

(15) They certainly looked official - dark suits, black shoes, short hair, long overcoats, clipped speech, efficient manners. (FGJ3E.s690)

Su aspecto era de lo más oficial: traje oscuro, zapatos negros, cabello corto, abrigo largo, lenguaje lacónico y pinta de personas competentes. (FGJ3S.s685)

(16) This fear is never openly discussed, and certainly not with the staff, though we all know. (FJPD1E.s67)

Nunca hablan sin reservas de ese temor, y mucho menos con el personal, pero todos lo sabemos. (FJPD1S.s67)

Another $4 \%$ of the translation solutions corresponded to cases where the degree of certainty was conveyed by means of a modulation into a clause containing the Spanish noun $d u d a$, "doubt" as in (17) and (18):

(17) Certainly if he had dropped that far, he would be badly injured. (FBD1E.s37)

No había duda de que si había caído desde aquella altura, estaría malherido. (FBD1S. s35)

(18) Forbidden sex had brought them together, and they certainly had to avoid that subject. (FGJ3E.s957)

El tema que compartían era el sexo prohibido y no cabía duda de que ambos tenían que evitarlo. (FGJ3S.s948)

Finally, regarding the use of a lexical verb to convey the epistemic force of the English adverb certainly, there was just one case involving the Spanish verb esperar followed by the subjunctive mood. This construction is one typical way for expressing doubt about a future event, and therefore epistemic modality, in Spanish, although it does not seem a popular translation solution in the case of the adverb certainly, according to our parallel corpus as it accounts for only $1 \%$ of cases.

Figure 1 below shows the various translation possibilities found for the adverb certainly in the P-ACTRES corpus.

FIGURE 1

Translation options for certainly in Spanish
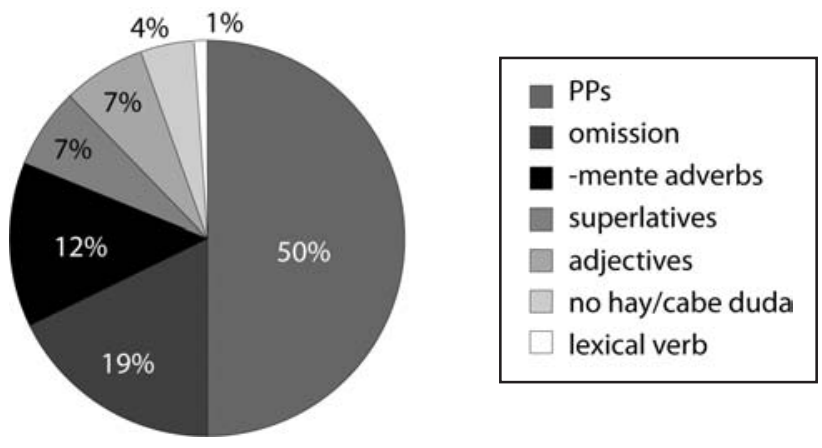
This brief analysis of the Spanish translations of the adverb certainly has revealed that PPs are clearly the preferred option for expressing the meanings conveyed by this particular adverb when expressing a degree of likelihood. Other resources such as adverbs ending in -mente, adjectival, clausal or lexical constructions occur much less frequently. The most interesting conclusion that can be derived from this analysis, though, is the fact that nearly $20 \%$ of cases of this adverb tend to be omitted in Spanish translations when there is an added pragmatic effect on top of the epistemic meaning. It appears that this omission does not generally affect the overall meaning of the translation, but simply results in a text that is less tightly woven together with textual and pragmatic links than the original.

\subsection{The translations of probably}

The adverb probably is one of the most common epistemic adverbs in English (Biber et al. 1999: 563). From a semantic perspective, the use of probably implies that

...the speaker's reasonable certainty that the propositional content of what he is saying is in fact true. [...] Probably is the most common item and the strength of likelihood it conveys is best understood if it is contrasted with the much weaker adverbs conceivably and possibly. (Hoye 1997: 194)

The P-ACTRES corpus contained 170 cases of probably, but 12 of these cases were not taken into account in the study as they corresponded to modifying uses in adjective phrases. In addition, another 2 cases had to be left out because the sentences in which the adverb occurred were entirely omitted in the target text. This leaves us with 156 instances of probably and their corresponding translations into Spanish. With respect to co-occurrence with modal verbs, probably appeared particularly often with the modals will (16 cases) and would (15 instances), and there was one case of co-occurrence with can and another one with should.

The translational options found in the parallel corpus for the English adverb probably are the following:

TABLE 3

Translations of probably in Spanish

RESOURCE

probablemente

seguramente

$e s+a d j+q u e$

lo más probable era que

Omisión

Lexical verb deber de + infinitive

Quizá(s)

Lexical verb suponer + infinitive

Con toda probablidad

Posiblemente

Presumiblemente

Tal vez

Sin duda

A buen seguro

Lexical verb poder

Lexical verb creer

TOTAL

\section{NUMBER OF CASES}

86

26

15

6

6

3

3

2

2

1

1

1

1

1

1

1

\section{PERCENTAGE}

$55.12 \%$

$16.66 \%$

$9.61 \%$

$3.84 \%$

$3.84 \%$

$1.92 \%$

$1.92 \%$

$1.28 \%$

$1.28 \%$

$0.64 \%$

$0.64 \%$

$0.64 \%$

$0.64 \%$

$0.64 \%$

$0.64 \%$

$0.64 \%$ 
The table shows that over half the occurrences of probably (55\% of cases) have been translated by the cognate Spanish adverb probablemente as in (19) and (20):

(19) Vladimir Putin, in Russia, would probably have a fit. (PKP1E.s41)

A Vladímir Putin, de Rusia, probablemente le daría un ataque. (PKP1S.s41)

(20) They probably ate all the time. (RGR1E.s244)

Probablemente se pasaban todo el tiempo comiendo. (RGR1S.s221)

This indicates that Spanish translators rely very heavily on this particular adverb for the expression of the intermediate degree of likelihood expressed by the English adverb probably. However, as mentioned in the analysis of certainly, -mente adverbs carry a strong stylistic connotation and generally tend to be avoided, although usage varies a lot from one adverb to another. Intralinguistic comparable data have shown that there is a significant overuse of probablemente in translated texts with respect to texts written originally in Spanish: 53 instances per million words in original Spanish texts versus 176 instances per million words in translated Spanish. This appears to be a clear case of translationese, since the difference is statistically significant ( $\mathrm{p}$-value $=0$ ). A similar feature has been found for this particular English adverb in Swedish translations (Aijmer 2001).

The next most common translational option (16.66\% of cases) has been another adverb ending in -mente with a very similar meaning, although slightly more colloquial: seguramente, as in (21). It may be claimed that the degree of certainty implied by this adverb is somewhat higher than the one implied by the English adverb probably.

(21) But the most pressing questions are probably the first two. (PATG11E.s39)

Pero las preguntas más acuciantes son seguramente las dos primeras. (PATG11S.s37)

Another two adverbs ending in -mente have been found as translation equivalents of probably: posiblemente and presumiblemente, with one case each. Here, the degree of likelihood appears to be somewhat lower than the one expressed in the English source text. This variation indicates the difficulty in conveying in a different language a semantic nuance that is so elusive as a particular degree of probability. The boundaries between semantic categories are always fuzzy, and probability can be said to be a cline rather than a clearly defined separate grouping. However, the relationship between meaning and the form used to expressed it is something that is quantifiable to a certain extent and in this case the analysis has shown that, all in all, over $73 \%$ of the translational options for this particular adverb correspond to -mente adverbs.

The next most frequently used resource has been the modulation of the semantic content of probably into a construction including a copula followed by an adjective indicating the degree of probability - probable (12 cases), posible (2 cases), previsible ( 1 case) - and followed by the particle "que" plus the verb in the subjunctive mood, as in (22) and (23) below:

(22) I probably played all the places at one time or another. (EDB1E.s268)

Es probable que tocara en todos los locales, como mínimo una vez. (EDB1S.s274)

(23) But you're probably right. (FJPD1E.s612)

Pero es posible que tengas razón. (FJPD1S.s625)

The subjunctive mood is a very common resource employed by native speakers of Spanish to indicate non-factuality, futurity and various degrees of probability and 
possibility. The modal meaning expressed exclusively by adverbial means in the English text is thus divided up into two separate parts in Spanish: a lexical part in the form of an adjective, and a further reinforcement of the uncertainty in the form of verbal mood.

A further 6 cases of probably were translated into a variant of this adjectival resource, but in the form of a highly idiomatic superlative construction in Spanish including the adjective probable and the subjunctive mood, as in (24) and (25):

(24) Probably she had gone shopping. (FFK1E.s555)

Lo más probable era que sólo hubiera salido a comprar. (FFK1S.s570)

(25) They'd probably been through this many times. (FGJ1E.s417)

Lo más probable era que todos ellos hubieran pasado muchas veces por aquella situación. (FGJ1S.s395)

Here the epistemic meaning is conveyed by the grammatical construction as a whole, which follows a fixed order. Again, as in the case of the adverb seguramente, I consider that there is an increase in the degree of certainty conveyed in the Spanish translation with respect to the English original. Superlatives are used here for epistemic modality, as is the case of certainly.

There were 7 cases in our corpus (4.48\% of the total) where probably was translated by a lexical verb or a verbal periphrasis indicating probability: deber de, suponer, creer and poder, as in examples (26) and (27):

(26) "Not to me, but then I'm probably the last person he would have confided in." (FJPD1E.s440)

- No, aunque supongo que soy la última persona a quien habría confiado algo semejante. (FJPD1S.s450)

(27) "You'll probably be fine." (FBW1E.s242)

"No creo que haya problemas." (FBW1S.s241)

In this last example, the degree of likelihood is expressed in the lexical verb creer followed by the subjunctive mood in the past tense reinforcing the attitude of the speaker with regard to the proposition and referring to the future time. In addition, the form of the original is greatly modulated with a change in polarity, from positive in the original to negative in the translation.

In 6 cases, the adverb probably was omitted in the Spanish translation, as in (28):

(28) I suppose the mix of states and international organisations is probably about right, although I don't see any good reason why the EU should have two representatives there; while the UN secretary general should be there as of right. (PATG11E.s38)

Supongo que la mezcla de Estados y organizaciones internacionales está bien, aunque no sé por qué tiene que contar la UE con dos representantes, mientras que, en mi opinión, el secretario general de la ONU debería estar por derecho propio. (PATG11S.s36)

Considering the size of our sample (156 instances), this is an indicator of the fact that this particular adverb does not tend to be omitted very often (about $4 \%$ of cases), its meaning being considered of importance for the transfer into the target language. In (28) it may be noted that the source text includes the lexical verb suppose, which indicates epistemic modality itself. The cognate lexical verb is used in Spanish, supongo, so the reinforcing modal meaning of probably is left out but the epistemic meaning is preserved to a certain extent in the form of the lexical verb. Again, this could be considered a downtoning of the epistemic force present in the English 
example. In none of these cases can probably be considered to have any pragmatic effect whatsoever on the meaning of the source text and the few omissions there are occur when other indicators of epistemic meanings are present and attenuate these omissions.

There were 4 cases of other epistemic adverbs not ending in -mente that have been chosen to express probability: tal vez and quizá(s) (2.56\% of the total), as in examples (29) and (30):

(29) "But probably less harmful to the human race than most of his other activities." (FJPD1E.s573)

- Pero quizá menos perjudicial para la raza humana que el resto de sus actividades. (FJPD1S.s583)

(30) Something told him no, that those days were gone, probably forever. (FGJ3E.s547) Algo le dijo que no, que aquellos días ya habían tocado a su fin, tal vez para siempre. (FGJ3S.s539)

Finally, the translational options for the English adverb probably included 4 instances of PPs, which indicates that this is not a particularly popular resource in Spanish for expressing the type of meanings conveyed by probably. Again the head word in the NP that follows the preposition is the one containing the epistemic force, as in examples (31) and (32):

(31) Miss Rayford might still demand testimony from Billie's cousin, but he would probably lie for her. (FFK1E.s351)

La señorita Rayford aún podía exigir el testimonio del primo de Billie, que con toda probabilidad mentiría por ella. (FFK1S.s364)

(32) Offered him iced coffee, probably to let him see Christine's status in the house. (FMT1E.s953)

Le ofreció café helado, sin duda para mostrarle cuál era la categoría de Christine en la casa. (FMT1S.s939)

The latter case again tends towards a higher degree of certainty in the translation than the one implied by the original English text, a trend that has already been noted in many other cases of the translation of this particular adverb. In fact, the PP sin $d u d a$ was one of the options taken in the case of the English adverb certainly, which indicates a higher degree of likelihood than probably.

Figure 3 below summarises graphically the translational options found in the P-ACTRES corpus for the adverb probably.

FIGURE 2

Translation options for probably in Spanish

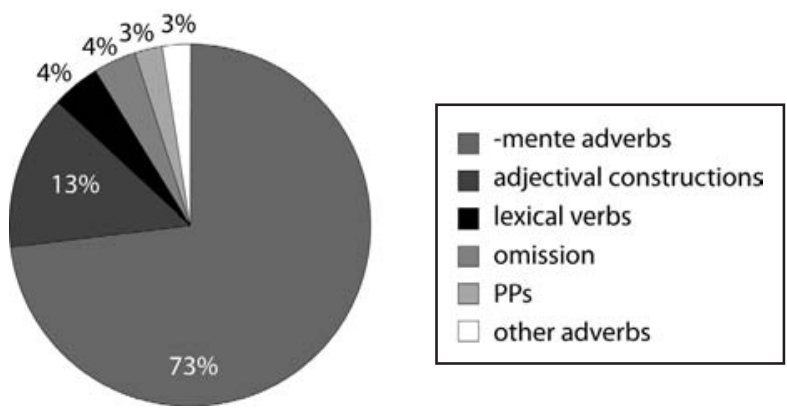


The vast majority of cases (73\%) have been translated using -mente adverbs in Spanish, predominantly probablemente, followed by seguramente, with two additional instances of one single adverb each. Indeed, there is a statistically significant overuse of probablemente in Spanish translations. Adjectival constructions of various types account for about $13 \%$ of cases and the remaining translational options, although highly idiomatic in Spanish, account for less than 5\% of cases each: lexical verbs, PPs and other adverbs not ending in -mente. It is striking that the adverb probably is omitted only in $4 \%$ of cases in Spanish translations, which seems to indicate that the meaning of epistemic modality conveyed by this adverb is considered as clearly relevant and important in the original and is therefore preserved in the translations. This is supported by the fact that the omissions occurred where other modal resources supplied part of the lost epistemic meaning (28). This result seems to indicate that probably is not an adverb that is likely to grammaticalize into a pragmatic marker in English.

\subsection{The translations of possibly}

The English adverb possibly is considered to express a lower degree of likelihood on the part of the speaker than the one conveyed by certainly and probably. The epistemic meaning conveyed by this adverb expresses a weak commitment on the part of the speaker with respect to the truth of the proposition. Quirk et al. (1985: 600) define the use of possibly as a downtoner or minimizer, on top of the expression of doubt. Biber et al. (1999: 972), consider that many stance markers are difficult to classify in one singular meaning group and consider that possibly may indicate not only doubt, but also precision or limitation.

The P-ACTRES corpus contained 43 instances of the English adverb possibly with their corresponding Spanish translations, but in 13 of these cases possibly was not functioning as a clause adverbial but as a modifier in an adjective phrase, and these cases were not considered for the study. Thus, 30 cases were finally analysed. Nearly half the occurrences showed possibly co-occurring with modal verbs: in 10 cases with could and in 4 cases with can. Both are pleonastic combinations, i.e., harmonic verb-adverb combinations. This high frequency of co-occurrence with modal verbs when compared with the frequency of co-occurrence of the other two adverbs analyzed previously seems to indicate that the semantic role fulfilled by possibly is not always considered to be strong enough to convey epistemic meanings on its own, but is rather used as a reinforcement of some epistemic modal verbs. Consequently, possibly seems to have an emphatic force and is, therefore, a good candidate for grammaticalization.

The translations found in Spanish for the adverb possibly are shown in Table 4 below:

TABLE 4

Translations of possibly in Spanish

TRANSLATION

Omission

Posiblemente

posible/imposible

en modo alguno
NUMBER OF CASES

13

6

4

2
PERCENTAGE

$43.33 \%$

$20 \%$

$13.33 \%$

$6.66 \%$ 
quizá(s)

tal vez

acaso

posibilidad

TOTAL
$6.66 \%$

$3.33 \%$

$3.33 \%$

$3.33 \%$

The data show that only about half of the occurrences of possibly (17 instances) have actually been translated into Spanish indicating epistemic modality. In almost half the cases (13 instances) the reinforcing status of the English modal adverb is completely lost in the Spanish translation. There were 2 cases of total omission of the adverb and the epistemic force involved in the original, as in (33):

(33) I can't possibly stay mad at you. (FBD1E.s800)

No sé estar enfadado contigo. (FBD1S.s744)

The meaning conveyed by the English adverb possibly cannot be considered to indicate only a low degree of likelihood, but rather a strong emphasis and personal involvement on the part of the speaker. It may even be argued that the particular combination found in the example closely resembles a collocation or at least a highly idiomatic expression in English often associated with exclamations and spoken conversation. The modal is fused together with a modally harmonic adverb forming something that resembles a single lexical unit used with an emphasizing purpose. Possibly is being used here mainly as a pragmatic marker. The adverb is omitted in the translation and the total omission of the semantic content of possibly is more idiomatic in Spanish than its translation would have been, i.e., less is more in this case. I will use the term "idiomatic omission" to refer to this phenomenon.

The most interesting fact, however, is that in 11 cases $(36.66 \%$ of the total) the content of the adverb is omitted but the epistemic force indicating possibility is still present in the translation, although greatly diminished, in the form of the Spanish lexical verb poder in various tenses. Again, in all of these cases, the English adverb possibly was used pleonastically to support a modal verb, can or could, as in example (34):

(34) "Professor Dumbledore will be back tomorrow," she said finally; "I don't know how you found out about the Stone, but rest assured, no one can possibly steal it, it's too well protected." (FRJK3E.s114)

- El profesor Dumbledore regresará mañana - dijo finalmente-. (FRJK3S.s119) No sé cómo habéis descubierto lo de la Piedra, pero quedaos tranquilos. (FRJK3S.s120) Nadie puede robarla, está demasiado bien protegida. (FRJK3S.s121)

In my opinion, these cases should not be considered simply as omissions, but rather as idiomatic omissions. Even though the exact semantic content of the adverb is not present in the Spanish texts, I claim that this is not only an appropriate translational solution, but actually the best option, since the Spanish verb poder does convey sufficient epistemic force and does not collocate with any Spanish adverb in the way can/could collocate with possibly to convey an emphatic meaning. Omitting the content of the adverb possibly results in a higher degree of idiomaticity in Spanish, as can be seen in examples (35) and (36):

(35) Sophie felt totally certain she had deciphered her grandfather's intentions correctly.

(FBD1E.s1317) What else could he possibly intend? (FBD1E.s1318) 
Sophie estaba segura de haber interpretado correctamente las intenciones de su abuelo.” ¿Qué otra cosa si no podría haber querido indicarme?” (FBD1S.h16)

(36) "But... how could you possibly know that!" (FBD1E.s864)

- Pero... ¿ ¿ómo puedes saber una cosa así? - le dijo, asombrada. (FBD1S.s806)

I claim that these omissions in the translations are a clear sign of the use of the English adverb possibly as a discourse marker in the corresponding source texts. In these cases the adverb is void of actual epistemic meaning of its own, but is used merely as an intensifier indicating great surprise on the part of the speaker and complementing the meaning of the modal verb it reinforces. This semantic shift is most clearly seen in spoken conversation or dialogue, as in examples (34) and (36).

The idiomatic omission was the most common translational option adopted by the Spanish translators, and this option corresponded to cases where the adverb possibly was used as an emphasizer rather than as epistemic adverb. This implies that, at least in our sample, which is admittedly limited, nearly half the instances of possibly were of this discourse marker type. Is this a sign of the grammaticalization of the English adverb, as found by Aijmer (2002)? I argue that the idiomatic omission in translations of certain traditionally so-called modal adverbs can be used as an indicator of the shift these adverbs have undergone in meaning and of their newly acquired uses as pragmatic and textual markers.

In the cases where possibly was not omitted, the translational options observed closely resemble the ones found in the two previous cases. About $20 \%$ of cases corresponded to the cognate Spanish adverb posiblemente, marking, in addition to a low degree of commitment, some type of limitation, as in example (37):

(37) Several of their descendants were burnt as witches in Salem in 1693, possibly because of the alarming nature of the disease. (ERM1E.s55)

Vanas de sus descendientes fueron quemadas por brujas en Salem en 1693, debido posiblemente a la alarmante naturaleza de la enfermedad. (ERM1S.s53)

As in the two previous cases, I have carried out a comparative study between the frequency of this adverb in original Spanish texts and in translations. Again, I found an overuse of possibly, which occurs 26 times per million words in original texts (CREA) and 40 times per million words in translated texts (P-ACTRES). However, this difference is not statistically significant, with a p-value of 0.015 .

There were 4 cases where the meaning of the English adverb possibly was modulated into an adjectival construction in Spanish using the corresponding adjective, as in example (38), where the translation reflects the epistemic meaning but not the pragmatic mark of the English adverb:

(38) The term has a few weeks to run and I wonder if I can possibly advance beyond the position I have reached now, if I could supplant a real athlete - I wonder if it is even worth trying... (FBW1E.s553)

Quedan pocas semanas para que se acabe el trimestre, y me pregunto si me resultará posible avanzar más allá de la posición que he alcanzado ahora, si puedo suplantar a un verdadero atleta, me pregunto si merece la pena intentarlo siquiera... (FBW1S. s550)

In 4 cases, the adverb possibly was translated by single-word adverbs that were not the cognate adverb in -mente, all of them clearly indicating possibility: acaso, quizá(s), tal vez. In all cases the adverbs occurred with the subjunctive mood in 
Spanish, thus indicating a combination of two linguistic resources for expressing the epistemic meaning: a lexical one (the adverb) and a morphological one (mood). Example (39) illustrates this option:

(39) Snape was looking murderous. (FRJK1E.s156) Possibly Lockhart had noticed, because he said, "Enough demonstrating!" (FRJK1E.s157)

Snape parecía dispuesto a matarlo, y quizá Lockhart lo notara, porque dijo: (FRJK1S. h2) - ¡Basta de demostración! (FRJK1S.s163)

There were 2 cases of a translation into the PP en modo alguno, which is rather formal in Spanish. In both cases the English adverb co-occurred with the modal could and was used as a modal reinforcement. The emphasizing effect is maintained in Spanish PP together with the lexical verb poder in the Spanish translations to reinforce the modal meaning, as in example (40):

(40) "Madam," said Arthur uncomfortably, "I don't wish to be rude, but I couldn't possibly ask one of my knights to marry you." (FBT1E.s38)

"Señora," dijo Arturo incómodo, "no quiero ser grosero, pero no podría pedir en modo alguno a ninguno de mis caballeros que se casara con vos." (FBT1S.s37)

Finally, the English adverb possibly was modulated into the Spanish noun posibilidad in one case, example (41):

(41) Possibly, photosynthesis arose once, early in the evolutionary history of the Eucarya, and was later lost in some lineages, including our own. (EKAH1E.s86)

Una posibilidad es que la fotosíntesis haya aparecido una sola vez al principio de la historia evolutiva de Eucarya para más tarde desaparecer de algunos linajes, incluido el nuestro. (EKAH1S.s83)

Figure 3 below summarizes all the translational options found in the P-ACTRES parallel corpus for the English adverb possibly:

FIGURE 3

\section{Translational options for possibly in Spanish}
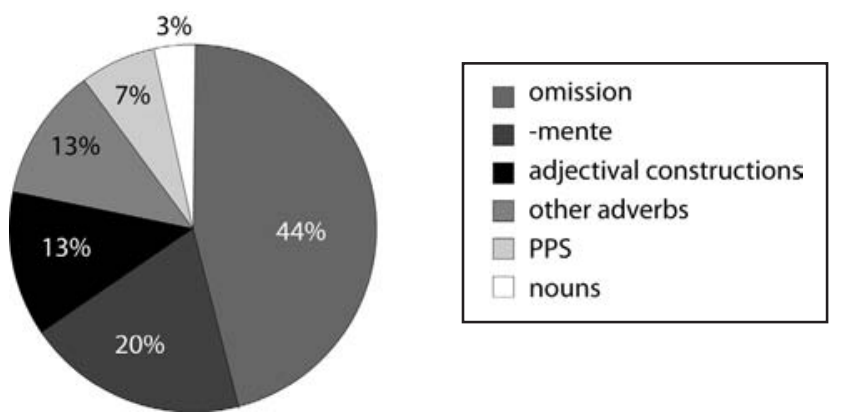

Even though the number of cases that have been analysed is relatively small, the distribution of the translational options can be considered sufficiently representative for our purposes here. Figure 3 shows that in nearly half of the cases (44\%) the English adverb possibly is omitted in Spanish translations. When the adverb is translated, the translational options are similar to the ones found for the adverbs analysed in the previous sections: $20 \%$ of the instances were translated with adverbs ending in mente, $13 \%$ of cases were translated using adjectival constructions and the same 
percentage corresponds to translations by means of other adverbs not ending in - mente. Finally, PPs and transposition into nouns show percentages under $10 \%$.

\section{Results and Discussion}

The results of the analysis described in the previous section illustrate that the translational options of the three epistemic adverbs selected differ substantially. Bearing in mind that all three are traditionally considered to belong to the same semantic group indicating different levels of likelihood, the data found in this analysis show that there are strong trends in the translation of these adverbs that suggest that they are used in discourse with very different functions from one another. We will discuss these differences in this section in order to try and determine whether the variations in the translational options reflect actual disparities in meaning in the source language. Figure 4 below shows the distribution of the four most common translational options found for the three epistemic adverbs analyzed in this paper: certainly, probably, possibly.

FIGURE 4

Translational options in Spanish for the adverbs certainly, probably and possibly
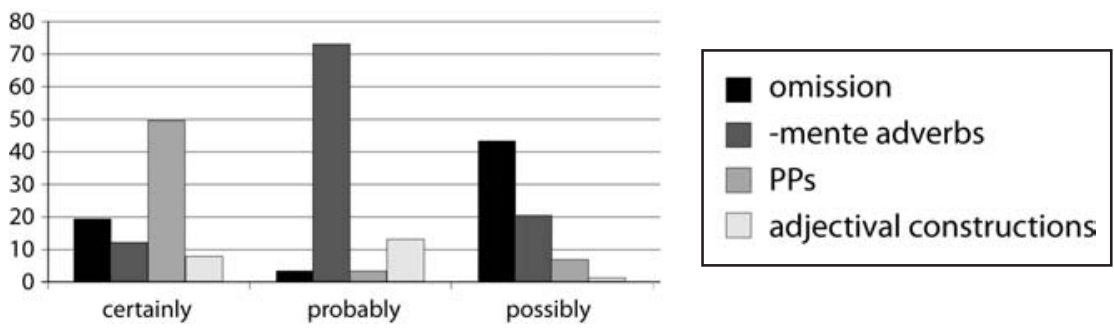

Figure 4 shows that each adverb has a different trend with respect to the translational possibilities found in Spanish. The meaning conveyed by certainly is translated most often as a PP in Spanish, the meaning of probably by the cognate -mente adverb, and the meaning of possibly is mostly omitted. In my opinion, these results suggest that translators identify a gradient between the degree of "adverbiality" of these three English adverbs: they seem to consider that probably is very clearly an adverb and tend to overuse the corresponding Spanish cognate and hardly ever omit it; certainly goes next in the cline of typically adverbial-like qualities, although it is mostly PPs that are used to express these meanings, and about $20 \%$ of cases are omitted, thus indicating that translators identify a particular pragmatic function in the source text that is not absolutely essential for understanding the meaning; finally, possibly is a clear case of an adverb that has acquired a very high degree of grammaticalization, as can be inferred from the way it is treated by Spanish translators, who consistently omit it in nearly $50 \%$ of cases, namely when it acts as a pragmatic marker.

Grammaticalization is a slow and gradual process, and the results of this study demonstrate that translations can be used to detect the degree to which a particular adverb has been grammaticalized into a pragmatic marker by taking into account 
the number of cases in which it is omitted in translations. Here, probably has shown to be an adverb that is unlikely to ever turn into a pragmatic marker, whereas certainly is on its way, and possibly has already attained a high degree of grammaticalization. This cannot be considered a hard-and-fast rule, but rather a strong trend. In other words, there may be cases where possibly is used as a pragmatic marker in English and translated with epistemic resources into Spanish, as in example (42).

(42) She can't possibly squeeze the Jeep between them. (FCJ1E.s1127)

Es imposible que el jeep pase entre ellos. (FCJ1S.s1106)

In this case the epistemic meaning is preserved (a modal verb appears in English too), and the pragmatic effect is achieved by the use of a highly modulated structure in the translation.

In addition to omissions in translations, the analysis carried out in this paper reveals that there are also other aspects that can be taken into account when trying to determine the degree of grammaticalization of a particular adverb, in particular the co-occurrence with modal adverbs. Figure 5 below shows the frequency of co-occurrence with modal verbs of the adverbs analyzed here:

FIGURE 5

Co-occurrence with modal verbs

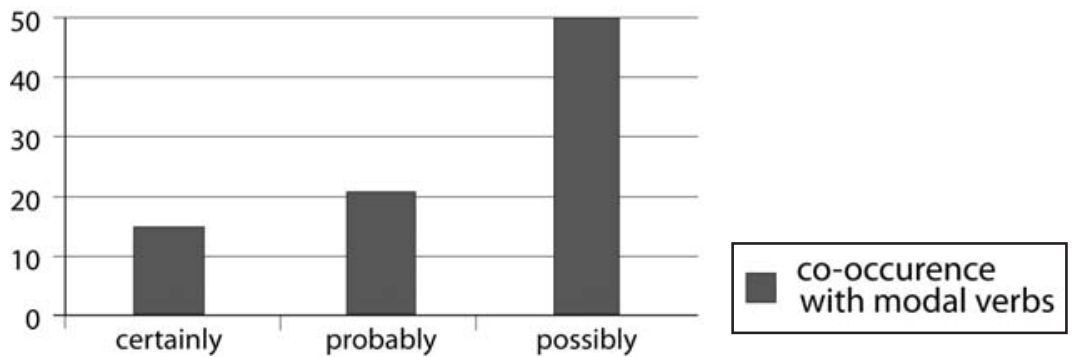

It can be seen that certainly co-occurs with modals in $15 \%$ of cases, probably in $21 \%$ of cases, and possibly in nearly $50 \%$ of cases. Again we can see that the data point clearly towards possibly as a candidate for a high degree of grammaticalization, since it appears very often reinforcing some modal verb, especially can and could. These combinations can be considered collocations or near-collocations and should be studied from the point of view of phraseology taking into account their highly idiomatic nature and the pragmatic function they fulfil in the English language.

As for the frequency distribution of -mente adverbs as translational options for the three epistemic adverbs analysed, Fig. 6 shows that in all three cases there is an overuse of -mente adverbs in Spanish translations when compared to texts written originally in Spanish. However, this difference is very small in the cases of ciertamente and posiblemente. In contrast, the difference is very high (and statistically significant for a p-value $<0.01$ ) for the Spanish adverb probablemente, which occurs nearly four times more often in translations than in original texts. One possible explanation for this fact is the influence of the source language English, where probably, the corresponding cognate, is used frequently. As we have already seen, this English adverb 
does not tend to be omitted from the translations because it is regarded as carrying an important semantic content, rather than a pragmatic connotation.

Figure 6

Number of occurrences per million words of running text

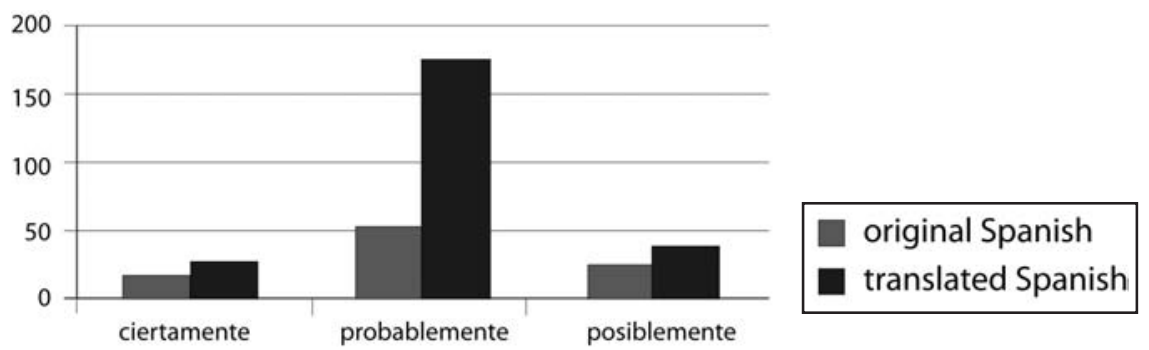

All the results discussed here point towards the fact that translators clearly relate probably to adverbial meanings, whereas the other two adverbs, even though cognates are available in Spanish, do not give rise to translationese mainly because they tend to be viewed more often as pragmatic markers and therefore tend to be omitted in translations.

\section{Conclusions}

In this paper three English epistemic adverbs and their translations into Spanish were analyzed, corresponding to three different degrees of likelihood: certainty, probability and possibility. The analysis of the Spanish translations of the adverbs certainly, probably and possibly has provided a number of interesting results.

Important differences have been found in the translational options most commonly employed for each of the adverbs analyzed. This confirms the importance of the lexical perspective in the analysis of any linguistic item, since only a lexically individualized research will provide data about the specific functions involved in the use of each of the English modal adverbs, their uses and their degree of grammaticalization. Certainly was mostly translated by means of PPs, probably mostly by the corresponding cognate in -mente and possibly was mostly omitted. Slight variations in the degree of likelihood expressed in the source texts and in the target texts were observed (generally a higher degree in translations), probably as a result of the fuzziness of epistemic meanings in general.

The present study has revealed that the frequency of co-occurrence of the modal adverb analyzed with modal verbs may be an indicator of the degree of grammaticalization of the adverb. This is particularly clear in the case of possibly, which tends to form collocations with certain modal verbs: can/could.

The most interesting result of the analysis in this paper concerns translations. The data revealed that when modal adverbs are omitted it is often because they did not really add a modal nuance to the content, but rather acted as grammaticalized textual or pragmatic discourse markers. The percentage of omissions in the translations can therefore be considered an indicator of the degree of grammaticalization of a particular modal adverb. The data have shown that of the three adverbs that have 
been analyzed, only probably is recognized as a proper adverb by Spanish translators, thus leading to a high number of -mente translations and very few cases of omission. In contrast, the uses of certainly and, especially, of possibly as pragmatic markers tend to be omitted for various reasons, including an attempt to make the translations more idiomatic in Spanish.

These differences in the translations take us to the main aim of this paper: to examine the role of translations in the identification of semantic functions of epistemic adverbs in English. I have argued in this paper that the actual disappearance of some modal markers in translations, in particular certain modal adverbs, may be an indicator of the pragmatic function of these linguistic items in the source language. In other words, translations can help distinguish the degree of grammaticalization and can therefore be considered a discriminating tool.

From a general translational perspective, the omission of pragmatic markers in translations may be considered as a general trend in translations. As found by Baker (1998, 2004), translated language, irrespective of the source language and of the target language, tends to show peculiar features when compared to native uses of the language. Translated language tends to be a simplified version of its original and the peculiarities of a language are levelled out. The omission of pragmatic markers may be considered as part of this simplification process observable in translations.

The results of this paper illustrate a process that is currently taking place in the English language and that requires careful study and analysis, i.e., the shift in the function of certain modal adverbs towards pragmatic uses. This must be taken into account in future descriptions of the English language. In addition, the present study has shown the usefulness of translation-based contrastive analyses for identifying these shifts in meaning in the source language through the translational possibilities offered by professional translators. The same method can be applied to other modal adverbs, and the procedure could also be adapted for discriminating various problematic uses of other linguistic items by employing translations. To conclude, the present analysis confirms that translations can be used as adequate tools for identifying varying degrees of a particular language shift.

\section{NOTES}

1. This paper was co-financed through the project HUM2005-01215/FILO by the Spanish Ministry of Education.

2. ACTRES is the Spanish acronym for "Contrastive Analysis and Translation English-Spanish."

3. We are grateful to Knut Hofland for his co-operation in the setting up of the P-ACTRES parallel corpus.

4. The chi-square test was used and the significance value was established at $\mathrm{p}<0.01$.

\section{REFERENCES}

Aijmer, K. (1999): "Epistemic Possibility in an English-Swedish Contrastive Perspective," in Hasselgård, H. and S. Oksefjell (eds.), Out of Corpora, Amsterdam, Rodopi, pp. 301-323.

Aijmer, K. (2001): "Probably in Swedish Translations - A Case of Translationese?," in Allén, S., Berg, S., Malmgren, S.-G., Norén, K. and B. Ralph (eds.), Gäller Stam, Suffix och Ord, Göteborg, Elanders Novum, pp. 1-13.

Aijmer, K. (2002): "Modal Adverbs of Certainty and Uncertainty in an English-Swedish Perspective," in Hasselgård, H., Johansson, S., Behrens, B. and C. Fabricius-Hansen (eds.), Information Structure in a Cross-linguistic Perspective, Amsterdam, Rodopi, pp. 97-112. 
Aijmer, K. (2005): "Evaluation and Pragmatic Markers," in Tognini-Bonelli, E. and G. Del Lungo Camiciotti (eds.), Strategies in Academic Discourse, Amsterdam and Philadelphia, John Benjamins, pp. 83-96.

Altenberg, B. (1999): "Adverbial Connectors in English and Swedish: Semantic and Lexical Correspondences," Hasselgård, H. and S. Oksefjell (eds.), Out of Corpora, Amsterdam, Rodopi, pp. 249-268.

BAKER, M. (1998): "Réexplorer la langue de la traduction: une approche par corpus," Meta 43-4, pp. $480-485$.

BAKER, M. (2004): "A corpus-based view of similarity and difference in translation," International Journal of Corpus Linguistics 9-2, pp. 167-193.

Biber, D. and E. Finegan (1989): "Styles of Stance in English: Lexical and Grammatical Marking of Evidentiality and Affect," Text, 9-1, pp. 93-124.

Biber, D., Johansson, S., Leech, G., Conrad, S. and E. Finegan (1999): Longman Grammar of Spoken and Written English, London, Longman.

Chafe, W. L. (1986): "Evidentiality in English Conversation and Academic Writing," in Chafe, W. L. and J. Nichols (eds.), Evidentiality: The Linguistic Coding of Epistemology, Norwood, N.J., Ablex, pp. 261-272.

Contes, J. (1983): The Semantics of the Modal Auxiliaries, London, Croom Helm.

Coates, J. (1995): “The Expression of Root and Epistemic Possibility in English," Bybee, J. and S. Fleischman (eds.), Modality in Grammar and Discourse, Amsterdam and Philadelphia, John Benjamins, pp. 55-66.

Facchinetti, R., Krug, M. and F. R. Palmer (eds.) (2003): Modality in Contemporary English, Berlin, Mouton.

Facchinetti, R. and F. R. Palmer (eds.) (2004): English Modality in Perspective. Genre Analysis and Contrastive Studies, Frankfurt am Main, Peter Lang.

Fraser, B. (1999): “What are Discourse Markers?,” Journal of Pragmatics 31, pp. 931-952.

Hale, B. (2000): "Modality," in Hale, B. and C. Wright (eds.), A Companion to Philosophy of Language, Oxford, Blackwell, pp. 487-515.

Halliday, M.A.K. (1994): An Introduction to Functional Grammar, London, Arnold.

Hoye, L. (1997): Adverbs and Modality in English, London, Longman.

Lyons, J. (1977): Semantics, Cambridge, CUP.

MÁrquez ReIter, R. (2005): "A Comparative Study of Certainty and Conventional Indirectness: Evidence from British English and Peninsular Spanish," Applied Linguistics 26-1, pp. 1-31.

Mauranen, A. (2000): "Strange strings in translated language: A study on corpora," in Olohan, M. (Ed.), Intercultural Faultlines. Research Models in Translation Studies I: Textual and Cognitive Aspects, Manchester, St. Jerome, pp. 119-141.

Mauranen, A. (2004): "Corpora, universals and interference," in Mauranen, A. and P. Kujaмäкi (Eds.), Translation Universals- Do they exist?, Amsterdam and Philadelphia, John Benjamins, pp. 65-82.

Nuyts, J. (2001): Epistemic Modality, Language, and Conceptualization, Amsterdam and Philadelphia, John Benjamins.

Palmer, F. R. (1979): Modality and the English Modals, London, Longman.

Palmer, F. R. (1990): Mood and Modality, Cambridge, CUP.

Perkins, M. R. (1983): Modal Expressions in English, London, Frances Pinter Publishers.

Quirk, R., Greenbaum, S., Leech, G. and J. Svartvik (1985): A Comprehensive Grammar of the English Language, London, Longman.

RABADÁN, R., LABRADOR, B. and N. RAMóN (2004): "English-Spanish Corpus-based Contrastive Analysis: Translational Applications from the ACTRES Project," in LewandowskaTомаszczyк, B. (Ed.), Practical Applications in Language and Computers - PALC 2003, Frankfurt am Main, Peter Lang, pp. 141-151.

RabadÁn, R., LABRAdor, B. and N. RAmón (2006): "Putting Meanings into Words: English -ly Adverbs in Spanish Translations," in Mourón Figueroa, C. and T.I. Moralejo Gárate (Eds.), Studies in Contrastive Linguistics. Proceedings of the 4th International Contrastive 
96 MetA, LIV, 1, 2009

Linguistics Conference, Santiago de Compostela, Universidad de Santiago de Compostela, pp. 855-862.

Ramón, N. (2003): Estudio contrastivo inglés-español de la caracterización de sustantivos, León, University of León.

Ramón, N. (2006): "Approaching Epistemic Modality in English and Spanish: A Corpus-based Contrastive Study of probably and probablemente," in Juan, M., Amengual, M. and J. SAlazAR (Eds.), Lingüística aplicada en la sociedad de la información y la comunicación, Palma de Mallorca, Universidad de las Islas Baleares, pp. 319-327.

Thompson, G. and S. Hunston (2000): "Evaluation. An Introduction," in Hunston, S. and G. Thompson (Eds.), Evaluation in Text. Authorial Stance and the Construction of Discourse, Oxford, OUP, pp. 1-27. 